\title{
PENGARUH PROSEDUR PEMBERIAN KREDIT TERHADAP PENGENDALIAN PIUTANG PADA PT. NUSA SURYA CIPTA DANA (NSC FINANCE) CABANG GORONTALO
}

\author{
Lukman Pakaya \\ Fakultas Ekonomi, Universitas Negeri Gorontalo \\ lukman@yahoo.com \\ Ayu Rakhma Wuryandini \\ Fakultas Ekonomi, Universitas Negeri Gorontalo \\ dinie.dinie66@gmail.com \\ Olista Koniyo \\ Fakultas Ekonomi, Universitas Negeri Gorontalo \\ olista.koniyo@gmail.com
}

\begin{abstract}
ABSTRAK
Penelitian ini bertujuan untuk mengetahui dan menguji apakah prosedur pemberian kredit berpengaruh terhadap pengendalian piutang pada PT. Nusa Surya Ciptadana (NSC Finance) Cabang Gorontalo.Metode penelitian yang digunakan adalah metode penelitian kuantitatif. Jenis data yang digunakan adalah data primer dengan menyebar kuiseoner. Sampel yang digunakan dalam penelitian ini adalah seluruh karyawan pada PT. Nusa Surya Ciptadana (NSC Finance) Cabang Gorontalo dengan jumlah 30 karyawan. Teknik pengumpulan sampel menggunakan sampling total atau yang dikenal dengan metode sensus.Teknik analisis data menggunakan uji kualitas instrumen dan metode Regresi Sederhana. Hasil penelitian ini menunjukkan bahwa terdapat pengaruh yang signifikan dari Prosedur pemberian kredit PT. Nusa Surya Ciptadana (NSC) Finance Cabang Gorontalo terhadap Pengendalian piutang di PT. Nusa Surya Ciptadana (NSC) Finance Cabang Gorontalo. Nilai Koefisien regresi dengan arah postif menunjukan terdapat pengaruh yang baik Prosedur pemberian kredit dalam pengendalian piutang pada PT. Nusa Surya Ciptadana (NSC) Finance Cabang Gorontalo. Hal tersebut juga terlihat dari nilai $R_{\text {Square }}$ sebesar $72,9 \%$.
\end{abstract}

Kata Kunci: Prosedur Pemberian Kredit, Pengendalian Kredit.

\section{Pendahuluan}

Perkembangan dunia usaha di Indonesia semakin kompetitif dari waktu ke waktu, sehingga menyebabkan setiap perusahaan harus siap menghadapi persaingan yang sangat ketat. Berdirinya suatu perusahaan dimaksudkan untuk selalu tumbuh dan berkembang serta berkelanjutan untuk mencapai tujuan dari usaha tersebut yakni memperoleh laba semaksimal mungkin dari kegiatan bisnis baik dalam bentuk barang atau jasa.

Strategi yang digunakan perusahaan untuk meningkatkan laba salah satunnya adalah melakukan penjualan dalam bentuk barang atau jasa secara kredit. Penjualan kredit tidak segera menghasilkan penerimaan kas tetapi menimbulkan piutang kepada konsumen atau yang disebut dengan piutang usaha dan barulah kemudian pada saat jatuh temponya terjadi aliran kas masuk yang berasal dari pengumpulan piutang tersebut. 
Piutang merupakan aspek yang sangat penting, bahkan menurut Ramana (2013) piutang menempati tempat kedua terpenting dalam asset perusahaan setelah persediaan sehingga pada beberapa perusahaan, piutang dijadikan sebuah dasar dalam asset perusahaan.Oleh karena itu penanganannya memerlukan perlakuan yang sangat khusus sehingga kerugian piutang tak tertagih dapat dihindari.Pengelolaan piutang sebagian besar dipengaruhi oleh kebijakan kredit dan prosedur penagihan terhadap piutang itu sendiri.Piutang merupakan salahsatu faktor yang sangat penting untuk diperhatikan karena berpegaruh terhadap likuiditas dan modal kerja suatu perusahaan sebab piutang usaha masuk dalam kategori harta lancar, sehingga diperlukan suatu penanganan dan pengelolaan yang baik oleh pihak manajemen.

Menurut Kuncoro dan Suhardjono (2002: 245) mengungkapkan bahwa prosedur kredit merupakan upaya lembaga keuangan untuk mengurangi risiko dari pemberian kredit, yang dimulai dengan tahapan penyusunan perencanaan perkreditan, proses pemberian keputusan kredit (prakarsa, analisis dan evaluasi, negosiasi, rekomendasi, dan pemberian keputusan kredit), penyusunan pemberian kredit, dokumentasi dan administrasi kredit, persetujuan pencairan kredit serta pengawasan dan pembinaan kredit. Sebelum memperoleh kredit, debitur terlebih dahulu harus melalui tahapan-tahapan penilaian mulai dari pengajuan proposal kredit dan dokumen-dokumen yang diperlukan, pemeriksaan keaslian dokumen, analisis kredit sampai dengan kredit dikeluarkan oleh pihak lembaga keuangan.

Tetapi pada kenyataannya, sampai sekarang masih banyak perusahaan yang mengeluhkan adanya kredit macet atau meningkatnya jumlah piutang tak tertagih. Meskipun perusahaan telah melakukan analisa sebelum mengotorisasi penjualan kredit sesuai prosedur yang telah ditetapkan, namun tidak jarang perusahaan juga mengalami kesalahan dalam memberikan analisa tersebut. Kesalahan dalam memberikan analisa ini disebabkan oleh pihak eksternal (survey) yang memberikan data tidak lengkap atau manipulasi ketika mengisi data konsumen dan pihak internal (kepala surveyor) mendukung data tersebut. Timbulnya permasalahan tersebut, selain karena adanya indikasi debitur yang tidak mau membayar kewajibannya juga terlihat dalam prosedur pemberian kredit yang ternyata mengalami penyimpangan atau tidak wajar.

Penelitian ini pernah dilakukan oleh Mointi (2013) tentang Pengaruh Pengendalian Intern Prosedur Pemberian Kredit Terhadap Tingkat Pengembalian Piutang Pada PT. Bank Sulut Cabang Limboto. Hasil penelitian menunjukkan bahwa pengendalian intern 
berpengaruh terhadap prosedur pemberian kredit. Koefisien determinasi atau angka Rsquare adalah menunjukan besarnya penerapan pengendalian intern dalam pemberian kredit berpengaruh secara signifikan terhadap tingkat pengembalian piutang.

Penelitian lainpun dilakukan oleh Nisa (2017) tentang Analisis Sistem Pengendalian Intern Persetujuan Kredit Dalam Memperkecil Resiko Piutang Tak Tertagih Pada PT. Nusa Surya Ciptadana Cabang Martapura. Hasil penelitian menunjukkan bahwa sistem pengendalian intern persetujuan kredit pada PT.Nusa Surya Ciptadana cabang Martapura masih belum sesuai dengan prinsip akuntansi berterima umum. Yang berdampak buruk terhadap piutang tak tertagih.

PT. Nusa Surya Ciptadana (NSC Finance) merupakan perusahaan leasing resmi honda yang melayani pembiayaan bagi konsumen yang ingin membeli motor kredit dan pembiayaan bagi konsumen yang akan menjaminkan unit motornya kepada dana tunai motor. Kegiatan memberikan kredit mengandung resiko terdapat banyak piutang tak tertagih dan tarik barang unit motor dikarenakan prosedur pemberian kredit kurang jelas yang disebabkan oleh bagian survey yang memberikan data tidak lengkap atau manipulasi ketika mengisi data konsumen. Kondisi ini semakin diperparah dengan kenyataan semakin meningkatnya kebutuhan hidup dari masyarakat, sehingga seringkali mereka tidak mampu untuk melunasi tagihan kreditnya saat jatuh tempo.

Tabel 1: Rekapitulasi Total Penjualan Kredit dan Piutang Tak Tertagih Periode 2015-2017

\begin{tabular}{cccc}
\hline Tahun & $\begin{array}{c}\text { Total Penjualan } \\
\text { Kredit }\end{array}$ & $\begin{array}{c}\text { Total Piutang Tak } \\
\text { Tertagih }\end{array}$ & $\begin{array}{c}\text { Barang Jaminan yang } \\
\text { di tarik Kembali }\end{array}$ \\
\hline 2015 & Rp. 1.300 .000 .000 & Rp. $207.000 .000 / 15.9 \%$ & Rp. $94.000 .000 / 7.2 \%$ \\
2016 & Rp. 2.100 .000 .000 & Rp. $706.000 .000 / 33.6 \%$ & Rp. $310.000 .000 / 14.7 \%$ \\
2017 & Rp. 1.000 .100 .000 & Rp. $406.000 .000 / 40.5 \%$ & Rp. $291.000 .000 / 29 \%$ \\
\hline
\end{tabular}

Sumber: PT. NSC Finance Cabang Gorontalo 2018

Berdasarkan data di atas, dapat dilihat bahwa total piutang tidak tertagih dan tarik barang unit motor meningkat dalam periode tahun 2015-2017. Timbulnya permasalahan tersebut, selain karena adanya indikasi debitur yang tidak mau membayar kewajibannya juga terlihat dalam prosedur pemberian kredit yang ternyata mengalami penyimpangan atau tidak wajar. Sehingga mengakibatkan tidak efektifnya tingkat pengembalian piutang. Jumlah pelanggan yang setiap tahunnya bertambah dan tidak dapat dipungkiri juga setiap tahunnya piutang tertagih pun terus meningkat. Sehingga perlu penanganan ketat dari manajemen kredit dalam hal prosedur pemberian kredit agar pengendalian piutang dapat terealisasi untuk 
meminimalisasi piutang tak tertagih, Karena dengan meminimalisasi piutang tak tertagih akan membantu perusahaan untuk dapat menjalankan proses operasinya dan dapat menjaga kelangsungan hidup organisasi.

Berdasarkan latar belakang tersebut, maka peneliti ingin mengetahui apakah terdapat pengaruh prosedur pemberian kredit terhadap pengendalian piutang. Adapun tujuan yang ingin dicapai dari penelitian ini adalah untuk menguji apakah prosedur pemberian kredit berpengaruh terhadap pengendalian piutang pada PT. Nusa Surya Ciptadana (NSC Finance) Cabang Gorontalo.

\section{Pustaka}

\section{Fungsi dan Unsur-unsur Pengendalian Internal}

Struktur utama dari pengendalian adalah adanya penetapan kebijakan dan prosedur yang dapat memberikan jaminan kewajaran dalam pencapaian tujuan. kebijakan dan prosedur yang ditetapkan diharapkan dapat memberikan peranan dalam mengatasi permasalahan yang timbul dalam mencapai tujuan usaha.

Pengendalian internal memiliki 3 (tiga) fungsi yang terdiri dari pencegahan (preventive control) yang merupakan pencegahan atas kemungkinan timbulnya suatu masalah sebelum masalah tersebut benar-benar muncul, fungsi pemeriksaan (detective control) dibutuhkan untuk mengungkap masalah etika masalah tersebut muncul dan fungsi sebagai korektif (corrective control) merupakan pemecahan masalah dari masalah yang ditemukan oleh fungsi pengendalian pemeriksaan yang mencakup pada proses identifikasi penyebab, perbaikan dan mengubah sistem agar masalah di masa depan dapat diminimalisasikan atau dihilangkan. (Romney dan Steinbert, 2006)

Perusahaan dapat mencapai tujuan pengendalian internal dan menjalankan fungsifungsi dari pengendalian dengan menerapkan unsur-unsur pengendalian internal. Menurut Standar Profesional Akuntan Publik (2001:319.2) unsur-unsur pengendalian internal terdiri dari 5 (lima) komponen, yaitu:

1. Lingkungan pengendalian, terdiri dari tindakan, kebijakan, dan prosedur yang mencerminkan keseluruhan sikap dari manajemen puncak, para direktur, dan pemilik dari suatu perusahaan mengenai arti pentingnya pengendalian internal bagi perusahaan tersebut. 
2. Penaksiran risiko, merupakan tindakan manajemen dalam memperhitungkan risiko yang dihadapi dan mengambil langkah-langkah penting untuk mengendalikan risiko tersebut agar tujuan dan pengendalian internal dapat tercapai.

3. Kegiatan Pengendalian, aktivitas pengendalian adalah kebijakan dan prosedur yang dibangun oleh manajemen untuk mencapai tujuan laporan keuangan yang obyektif.

4. Informasi dan komunikasi, komunikasi dan informasi tentang operasi pengendalian internal memberikan substansi yang dapat digunakan manajemen untuk mengevaluasi efektivitas pengendalian dan untuk mengelola operasinya. Sistem informasi harus benar-benar mencerminkan kondisi yang sebenarnya, akurat, dan lengkap. Informasi ini dapat meliputi jumlah piutang selama periode tertentu, data pelanggan, umur piutang, hingga pencatatan transaksi yang tercakup dalam pengolahan dan pelaporan transaksi. Selain itu, kominikasi juga menjadi kegiatan penting dalam kaitannya dengan pengendalian. Pentingnya komunikasi untuk memastikan agar data-data yang ada telah terslurkan dengan benar tanpa mengandung makna-makna yang bisa dan menyesatkan perusahaan.

5. Pengawasan dan pemantauan, proses ini dilaksanakan melalui kegiatan yang berlangsung secara terus-menerus, evaluasi secara terpisah, atau dengan berbagai kombinasi dari keduanya.

\section{Pengendalian Internal Piutang}

Menurut Hasibuan (2007:165) pengendalian piutang adalah usaha-usaha untuk menjaga piutang yang diberikan tetap lancar, produktif dan tidak macet. Pengendalian internal atas piutang usaha, sesungguhnya yang menjadi pusat perhatian adalah bagaimana pengamanan yang efesien dan efektif dilakukan atas piutang usaha, baik dari segi pengamanan atas perolehan fisik kas, pemisahan tugas (termasuk masalah otorisasi persetujuan kredit), sampai pada tersedianya data catatan akuntansi yang akurat.Setiap pengajuan kredit yang dilakukan oleh calon pembeli haruslah diuji atau dievaluasi terlebih dahulu kelayakan kreditnya.Bagian penjualan tidak boleh merangkap bagian kredit. Persetujuan pemberian kredit hanya boleh dilakukan oleh manajer kredit.(Hery, 2012:270).

Untuk mewujudkan pengendalian intern dan pengawasan terhadap piutang, maka perusahaan perlu memperhatikan hal-hal sebagai berikut:

1) Pemberian kredit dagang 
Kebijakan kredit dan syarat penjualan harus tidak menghalangi penjualan kepada para pelanggan yang sehat keadaan keuangannya, dan juga tidak boleh menimbulkan kerugian yang besar karena adanya piutang sangsi yang berlebihan.

2) Penagihan

Pelaksanaan penagihan merupakan upaya tindak lanjut dari kebijakan pemberian kredit dimana telah ditetapkan mengenai syarat-syarat pemberian kredit diantaranya syarat jatuh tempo pembayaran. Perusahaan dapat melakukan pengendalian piutang yang saat jatuh tempo belum melakukan pembayaran dengan dimulai dari cara pengiriman surat tagihan kepada para debitur, melalui telepon, melalui petugas yang datang ke debitur, atau melalui tindakan secara hukum.

3) Penetapan dan penyelenggaraan pengendalian intern yang tepat

Adanya pengendalian intern yang tepat atas piutang diperlukan guna mendukung tahap pengendalian seperti penetapan pemberian kredit dan pelaksanaan penagihan. Dalam penetapan pengendalian intern atas piutang ini, perusahaan harus memiliki prosedurprosedur yang tepat seperti:

a) Memisahkan fungsi pegawai atau bagian yang menangani transaksi penjualan dan fungsi akuntansi untuk piutang. Dengan demikian pegawai yang menangani akuntansi untuk piutang usaha tidak boleh dilibatkan dengan aspek operasi seperti

b) Pegawai yang menangani akuntansi piutang harus dipisahkan dari fungsi penerimaan hasil tagih piutang.

c) Semua transaksi pemberian kredit, pemberian potongan, dan penghapusan piutang harus mendapat persetujuan dari pejabat yang berwenang.

d) Piutang harus dicatat dalam buku tambahan piutang. Total dari saldo-saldo buku tambahan ini harus dicocokkan dengan buku besar yang bersangkutan, paling tidak sebulan sekali. Disamping itu, pada akhir bulan para debitur harus dikirimkan surat pernyataan piutang.

e) Perusahaan harus membuat daftar piutang berdasarkan umurnya (aging schedule).

\section{Penilaian Kredit}

Menurut Fahmi (2013) dalam memutuskan pemberian kredit atau melakukan pencairan dana melalui kredit maka ada beberapa hal yang harus dipikirkan baik oleh 
kreditur atau juga debitur secara umum dan itu sudah menjadi penilaian umum, yaitu yang biasa dikenal dengan lima C (5C). Prinsip 5C yaitu:

\section{1) Character (karakteristik)}

Ini menyangkut dengan sisi psikologis calon penerima kreditur itu sendiri, yaitu karakteristik atau sifat yang dimilikinya, seperti latar belakang keluarganya, hobi, cara hidup yang dijalani, kebiasaan-kebiasaannya. Tinjauan karakteristik ini bisa dilihat pada bagaimana ia melakukan keputusan bisnis selama ini dalam hal ketepatan waktu yang menyangkut dengan perjanjian atau kesepakatan-kesepakatan yang telah dilakukan selama ini.

2) Capacity (kemampuan)

Capacity adalah menyangkut dengan kemampuan seorang pebisnis mengelola usahanya, terutama pada masa-masa sulit sehingga nanti akan terlihat \|ability to pay\| atau kemampuan membayar.

3) Capital (modal)

Ini menyangkut dengan kemampuan modal yang dimiliki oleh seseorang pada saat ia melaksanakan bisnisnya tersebut.

4) Collateral (jaminan)

Collateral atau yang biasa disebut dengan jaminan adalah barang atau sesuatu yang dapat dijadikan jaminan pada saat seseorang akan melakukan peminjaman dana dalam bentuk kredit ke sebuah perbankan atau leasing.

e) Condition of economy (kondisi perekonomian)

Kondisi perekonomian yang tengah berlangsung di suatu negara seperti tingkat pertumbuhan ekonomi yang tengah terjadi, angka inflasi, jumlah pengangguran, purchasing power parity (daya beli), penerapan kebijakan moneter sekarang dan yang akan datang, dan iklim dunia usaha yaitu regulasi pemerintah, serta situasi ekonomi internasional yang tengah berkembang adalah bagian penting untuk dianalisa dan dijadikan bahan pertimbangan.

\section{Metode}

Metode penelitian yang digunakan adalah deskriptif dengan pendekatan kuantitatif, dimana hasil penelitian kuantitatif dideskripsikan dengan memberikan penjelasan mengenai pengaruh prosedur pemberian kredit terhadap pengendalian piutang. Adapun populasi dalam 
penelitian ini yaitu 30 karyawan PT. NSC yang terdiri dari 1 orang bagian Pic Marketing, 2 orang Team Leader Marketing (KDH Dana Tunai), 6 orang Agen Dana Tunai, 1 orang Pic Survey/CMS, 2 orang CMO, 1 orang bagian Pic Piutang, 2 orang bagian Teller, 2 orang Chekcker, 10 Orang Kolektor, 2 orang ADHdan 2 orang DCA. Teknik pengambilan sampel dalam penelitian ini menggunakan sampling total atau yang dikenal dengan metode sensus. Menurut Sugiyono (2017) sampling total adalah teknik penentuan sampel bila semua anggota populasi digunakan sebagai sampel. Sehingga jumlah sampel dalam penelitian ini adalah sama dengan jumlah populasi yang akan dijadikan responden.

Data yang digunakan dalam penelitian ini adalah data primer. Data primer dalam penelitian ini diperoleh melalui kuesioner yang telah disebar kepada responden dengan menggunakan skala likert dengan bobot 1 sangat tidak setuju dan 5 sangat setuju. Analisis data dengan menggunakan perhitungan statistik dari kuesioner yang telah disebarkan dengan tahapan-tahapan perhitungan sebagai berikut:

1. Uji Kualitas Instrumen

Instrumen penelitian diuji coba dengan tujuan untuk mengetahui apakah instrumen tersebut telah memenuhi persyaratan ditinjau dari segi kesahihan (validitas) maupun dari segi keandalan (reliabilitas).

A. Uji Validitas

$$
r_{x y}=\frac{n \sum x y-\left(\sum x\right)\left(\sum y\right)}{\sqrt{\left.\left(n \sum x^{2}-\left(\sum x\right)^{2}\right)\left(n \sum y^{2}\right)-\left(\sum y\right)^{2}\right)}}
$$

Pengujian validitas data dalam penelitian ini dilakukan dengan menggunakan metode Product Moment dari Karl Person dengan ketentuan jika $r$ hitung lebih besar dari $\mathrm{r}$ tabel maka skor butir pertanyaan kusioner valid.Sebaliknya jika $r$ hitung lebih kecil dari $r$ tabel maka skor butir pertanyaan kuesioner tidak valid. Suatu pertanyaan dikatakan valid dan dapat mengukur variabel penelitian yang dimaksud jika nilai koefisien validitasnya $>0,3$ atau $=0,3$ dan apabila $<0,3$ berarti data tersebut dikatakan tidak valid. Rumus pengujian validitas instrument dengan menggunakan metode Product Moment yakni sebagai berikut. Dimana:

$\mathrm{r} \quad=$ Koefisien validitas butir pernyataan yang dicari

$\mathrm{n} \quad=$ Banyaknya responden (diluar sampel penelitian yang sebenarnya)

$\mathrm{X}=$ skor yang diperoleh subyek dari seluruh item 
$\mathrm{Y}=$ skor total yang diperoleh dari seluruh item

$\sum \mathrm{x}=$ Jumlah skor dalam distribusi $\mathrm{x}$

$\sum \mathrm{y}=$ jumlah skor dalam distribusi $\mathrm{y}$

$\sum \mathrm{x} 2=$ Jumlah kuadrat masing-masing distribusi $\mathrm{x}$

$\sum y 2=$ jumlah kuadrat masing-masing $y$

Untuk lebih memudahkan perhitungan maka dilakukan dengan menggunakan bantuan program SPSS (Statistical Package for Social Science) dari Microsoft excel 2007.

\section{B. Uji Reliabilitas}

Untuk mengukur reliabilitas kuesioner dalam penelitian ini digunakan -Metode Alpha Cronbach\| dengan rumus:

$$
r_{11}=\left(\frac{k}{(k-1)}\right)\left(1-\frac{\Sigma \sigma_{t}^{2}}{\sigma_{t}^{2}}\right)
$$

Dimana:

r11 = reliabilitas instrumen

$\mathrm{k} \quad=$ banyaknya butir pertanyaan

$\sum \sigma \mathrm{t} 2=$ Jumlah varian butir

$\sigma \mathrm{t} 2=$ Varian total

Hasil uji reliabilitas — jika koefisien reliabilitas (Cronbach's Alpha) mendekati angka 1 sangat baik, jika berada di atas 0,8 baik, tetapi jika berada di bawah 0,6 tidak baik. Artinya jika nilai Alpha berada di bawah 0,6 maka dapat dikatakan bahwa pengukuran yang dilakukan tidak konsisten atau pengukuran tidak reliable.

\section{Analisis Regresi Linear Sederhana}

Teknik analisis data yang digunakan dalam penelitian ini adalah analisis regresi linear sederhana dengan menggunakan SPSS. Penggunaan teknis ini dikarenakan dalam penelitian ini hanya terdapat satu variabel terikat dan satu variabel bebas. Meodel yang akan dibentuk sesuai dengan tujuan penelitian adalah sebagai berikut: (Sugiyono, 2013)

$$
\mathrm{Y}=\mathrm{a}+\mathrm{bX}
$$

Dimana :

Y : Variabel dependen (Pengendalian piutang)

$\mathrm{X}$ : Variabel independen (Prosedur pemberian kredit) 
a : Angka arah atau koefisien regresi

b : intercept atau konstanta

\section{Hasil dan Pembahasan}

\section{Pengujian Kualitas Instrumen Variabel X}

Adapun kriteria pengujian validitas adalah dengan membandingkan nilai $\mathbf{r}_{\text {hitung }}$ dengan nilai $r_{\text {tabel. }}$ Jika, $r_{\text {hitung }}>r_{\text {tabel }}$ berarti dinyatakan valid, sebaliknya $r_{\text {hitung }}<r_{\text {tabel }}$ berarti tidak valid.

Jumlah pernyataan yang digunakan untuk mengukur pengaruh penerapan Prosedur pemberian kredit dalam penelitian ini sebanyak 15 pernyataan yang diuji pada 30 responden $(n=30)$. Pengujian validitas pernyataan tersebut sebagai berikut:

Tabel 2: Hasil Uji Validitas Variabel Prosedur Pemberian Kredit

\begin{tabular}{|c|c|c|c|c|}
\hline Pernyataan & rHitung & $\mathbf{r}_{\text {Tabel }}(\mathbf{n}=\mathbf{3 0})$ & Keterangan & Status \\
\hline 1 & 0,359 & \multirow{3}{*}{$\mathrm{df}=\mathrm{n}-2(30-$} & rHitung $>$ rTabel & Valid \\
\hline 2 & 0,697 & & rHitung $>$ rTabel & Valid \\
\hline 3 & 0,688 & & rHitung $>$ rTabel & Valid \\
\hline 4 & 0,672 & \multirow[t]{5}{*}{$2=28)$} & rHitung $>$ rTabel & Valid \\
\hline 5 & 0,471 & & rHitung $>$ rTabel & Valid \\
\hline 6 & 0,711 & & rHitung $>$ rTabel & Valid \\
\hline 7 & 0,654 & & rHitung $>$ rTabel & Valid \\
\hline 8 & 0,677 & & rHitung $>$ rTabel & Valid \\
\hline 9 & 0,667 & \multirow[t]{7}{*}{0,3061} & rHitung>rTabel & $\overline{\text { Valid }}$ \\
\hline 10 & 0,387 & & rHitung >rTabel & Valid \\
\hline 11 & 0,930 & & rHitung $>$ rTabel & Valid \\
\hline 12 & 0,751 & & rHitung $>$ rTabel & Valid \\
\hline 13 & 0,381 & & rHitung $>$ rTabel & Valid \\
\hline 14 & 0,552 & & rHitung >rTabel & Valid \\
\hline 15 & 0,828 & & rHitung $>$ rTabel & Valid \\
\hline
\end{tabular}

Sumber: Data olahan SPSS 21, 2018

Dalam pengujian validitas, pernyataan dikatakan valid jika $r_{\text {hitung }}$ lebih besar dari $r_{\text {tabel }}$. Nilai $r_{\text {tabel }}$ didapatkan dari tabel rho dimana $n=30$ dan tingkat signifikan 0,05 (5\%) maka nilai $\mathrm{r}_{\text {tabel }}$ sebesar 0,3061. Dengan demikian dari 15 pernyataan yang digunakan untuk mengukur pengaruh dari variabel Prosedur pemberian kredit, semua pernyataan telah memiliki nilai $\mathrm{r}_{\text {hitung }}$ lebih besar dari $\mathrm{r}_{\text {tabel }}$ 0,3061 sehingga dikatakan memenuhi uji validitas dan dapat digunakan untuk pengumpulan data penelitian.

Kemudian uji reliabilitas dilakukan terhadap item pernyataan yang dinyatakan valid.Pada penelitian ini, uji reliabilitas dilakukan dengan pendekatan internal consistency 
realibilty yang menggunakan tehnik alpha croncbach. Pengambilan keputusan berdasarkan nilai alpha Cronbach jika nilai Alpha melebihi atau sama dengan 0,6 maka pernyataan variabel tersebut reliabel dan sebaliknya (Ghozali, 2005).

Hasil pengujian reliabilitas untuk variabel Prosedur pemberian kredit dapat disajikan berikut ini:

Tabel 3: Hasil Pengujian Reliabilitas Prosedur pemberian kredit

\begin{tabular}{ccccc}
\hline & $\begin{array}{c}\text { Scale Mean if Item } \\
\text { Deleted }\end{array}$ & $\begin{array}{c}\text { Scale Variance if } \\
\text { Item Deleted }\end{array}$ & $\begin{array}{c}\text { Corrected Item- } \\
\text { Total Correlation }\end{array}$ & $\begin{array}{c}\text { Cronbach's Alpha } \\
\text { if Item Deleted }\end{array}$ \\
\hline X1 & 60,5667 & 33,702 &, 282 &, 898 \\
X2 & 60,6000 & 30,800 &, 637 &, 886 \\
X3 & 60,7333 & 31,513 &, 636 &, 887 \\
X4 & 60,7333 & 30,823 &, 605 &, 887 \\
X5 & 60,5333 & 33,016 &, 401 &, 895 \\
X6 & 60,5333 & 30,671 &, 653 &, 886 \\
X7 & 61,0000 & 31,586 &, 596 &, 888 \\
X8 & 61,2333 & 30,047 &, 598 &, 888 \\
X9 & 60,7333 & 29,926 &, 582 &, 889 \\
X10 & 60,1667 & 34,144 &, 336 &, 896 \\
X11 & 60,8000 & 29,062 &, 913 &, 875 \\
X12 & 60,7333 & 30,202 &, 698 &, 884 \\
X13 & 60,5333 & 33,568 &, 304 &, 898 \\
X14 & 60,5000 & 32,534 &, 488 &, 892 \\
X15 & 61,0667 & 27,306 &, 769 &, 880 \\
\hline
\end{tabular}

Sumber: Data Olahan SPSS 21, 2018

Berdasarkan hasil analisis dengan menggunakan teknik alpha croncbach sebagaimana yang disajikan pada tabel 6 di atas seluruh nilai koefisien reliabilitas Cronbach's Alpha t lebih besar dari nilai patokan yang telah ditentukan yaitu 0.6. Hal ini menunjukan bahwa instrumen pernyataan variabel Prosedur pemberian kredit dapat dipercaya dan dapat digunakan untuk penelitian selanjutnya.

\section{Pengujian Kualitas Instrumen Variabel Y}

Adapun kriteria pengujian validitas adalah dengan membandingkan nilai $\mathbf{r}_{\text {hitung }}$ dengan nilai $r_{\text {tabel }}$. Jika, $r_{\text {hitung }}>r_{\text {tabel }}$ berarti dinyatakan valid, sebaliknya $r_{\text {hitung }}<r_{\text {tabel }}$ berarti tidak Valid. Jumlah pernyataan yang digunakan untuk mengukur pengaruh penerapan Pengendalian piutang dalam penelitian ini sebanyak 12 pernyataan yang diuji pada 30 responden $(n=30)$. Pengujian validitas pernyataan tersebut sebagai berikut: 
Tabel 4: Hasil Uji Validitas Variabel Pengendalian piutang

\begin{tabular}{|c|c|c|c|c|}
\hline Pernyataan & $\begin{array}{c}\mathbf{r} \\
\text { Hitung }\end{array}$ & $\mathbf{r}_{\text {Tabel }}(\mathbf{n}=\mathbf{3 0})$ & Keterangan & Status \\
\hline 1 & 0,572 & \multirow{4}{*}{$\mathrm{df}=\mathrm{n}-2(30-$} & rHitung>rTabel & Valid \\
\hline 2 & 0,313 & & rHitung >rTabel & Valid \\
\hline 3 & 0,406 & & rHitung >rTabel & Valid \\
\hline 4 & 0,506 & & rHitung $>$ rTabel & Valid \\
\hline & & \multirow[t]{5}{*}{$2=28)$} & & \\
\hline 5 & 0,765 & & rHitung $>$ rTabel & Valid \\
\hline 6 & 0,758 & & rHitung $>$ rTabel & Valid \\
\hline 7 & 0,715 & & rHitung $>$ rTabel & Valid \\
\hline 8 & 0,436 & & rHitung $>$ rTabel & Valid \\
\hline & & \multirow[t]{5}{*}{0,3061} & & \\
\hline 9 & 0,720 & & rHitung $>$ rTabel & Valid \\
\hline 10 & 0,602 & & rHitung $>$ rTabel & Valid \\
\hline 11 & 0,538 & & rHitung >rTabel & Valid \\
\hline 12 & 0,543 & & rHitung $>$ rTabel & Valid \\
\hline
\end{tabular}

Sumber: Data Olahan SPSS 21, 2018

Dari pengujian validitas dinyatakan valid jika $r_{\text {hitung }}$ lebih besar dari $r_{\text {tabel }}$. Nilai $r_{\text {tabel }}$ didapatkan dari tabel rho dimana $\mathrm{n}=30$ dan tingkat signifikan $5 \%$, maka nilai $\mathrm{r}_{\text {tabel }}$ sebesar 0,3061. Dengan demikian dari 12 pernyataan yang digunakan untuk mengukur pengaruh dari variabel Pengendalian piutang, semua pernyataan telah memiliki nilai $r_{\text {hitung }}$ lebih besar dari $\mathrm{r}_{\text {tabel }}$ 0,3061 sehingga dikatakan memenuhi uji validitas dan dapat digunakan untuk pengumpulan data penelitian. Kemudian uji reliabilitas dilakukan terhadap item pernyataan yang dinyatakan valid. Pada penelitian ini, uji reliabilitas dilakukan dengan pendekatan internal consistency realibilty yang menggunakan tehnik alpha croncbach. Pengambilan keputusan berdasarkan nilai alpha Cronbach jika nilai Alpha melebihi atau sama dengan 0,6 maka pernyataan variabel tersebut reliabel dan sebaliknya (Ghozali, 2005).

Hasil pengujian reliabilitas untuk variabel Pengendalian piutang dapat disajikan berikut ini: 
Tabel 5: Hasil Pengujian Reliabilitas Pengendalian piutang

\begin{tabular}{ccccc}
\hline & $\begin{array}{c}\text { Scale Mean if Item } \\
\text { Deleted }\end{array}$ & $\begin{array}{c}\text { Scale Variance if } \\
\text { Item Deleted }\end{array}$ & $\begin{array}{c}\text { Corrected Item- } \\
\text { Total Correlation }\end{array}$ & $\begin{array}{c}\text { Cronbach's Alpha } \\
\text { if Item Deleted }\end{array}$ \\
\hline Y1 & 46,8667 & 24,533 &, 419 &, 880 \\
Y2 & 46,6667 & 25,540 &, 247 &, 888 \\
Y3 & 46,7000 & 23,183 &, 519 &, 875 \\
Y4 & 46,6000 & 23,972 &, 535 &, 874 \\
Y5 & 46,5667 & 22,875 &, 716 &, 864 \\
Y6 & 46,8000 & 21,131 &, 759 &, 859 \\
Y7 & 46,5333 & 21,085 &, 808 &, 856 \\
Y8 & 46,2667 & 23,444 &, 532 &, 874 \\
Y9 & 46,6333 & 22,723 &, 652 &, 867 \\
Y10 & 46,5000 & 23,776 &, 582 &, 871 \\
Y11 & 46,2333 & 22,944 &, 616 &, 869 \\
Y12 & 46,0667 & 24,340 &, 530 &, 874 \\
\hline
\end{tabular}

Sumber: Data Olahan SPSS 21, 2018

Berdasarkan hasil analisis dengan menggunakan teknik alpha croncbach sebagaimana yang disajikan pada tabel 8 di atas seluruh nilai koefisien reliabilitas Cronbach's Alpha tlebih besar dari nilai patokan yang telah ditentukan yaitu 0.6. Hal ini menunjukan bahwa instrumen pernyataan variabel Pengendalian piutang dapat dipercaya dan dapat digunakan untuk penelitian selanjutnya.

\section{Analisis Regresi Sederhana}

Analisis regresi sederhana digunakan untuk melihat pengaruh variabel bebas terhadap variabel terikat serta memprediksi nilai variabel terikat dengan menggunakan variabel bebas. Setelah dilakukan uji asumsi normalitas dan ternyata dipenuhi, tahap selanjutnya dilakukan pemodelan data dengan menggunakan analisis regresi sederhana. Pengujian hipotesis ini dilakukan melalui tahapan-tahapan untuk mencari persamaan regresi.

Dalam perhitungan persamaan regresi, digunakan suatu persamaan umum yaitu:

$$
\mathrm{Y}=\mathrm{a}+\mathrm{bX}
$$

Regresi dengan menggunakan program SPSS 21 yang disajikan pada tabel dibawah ini: 
Tabel 6: Pengujian Model Regresi

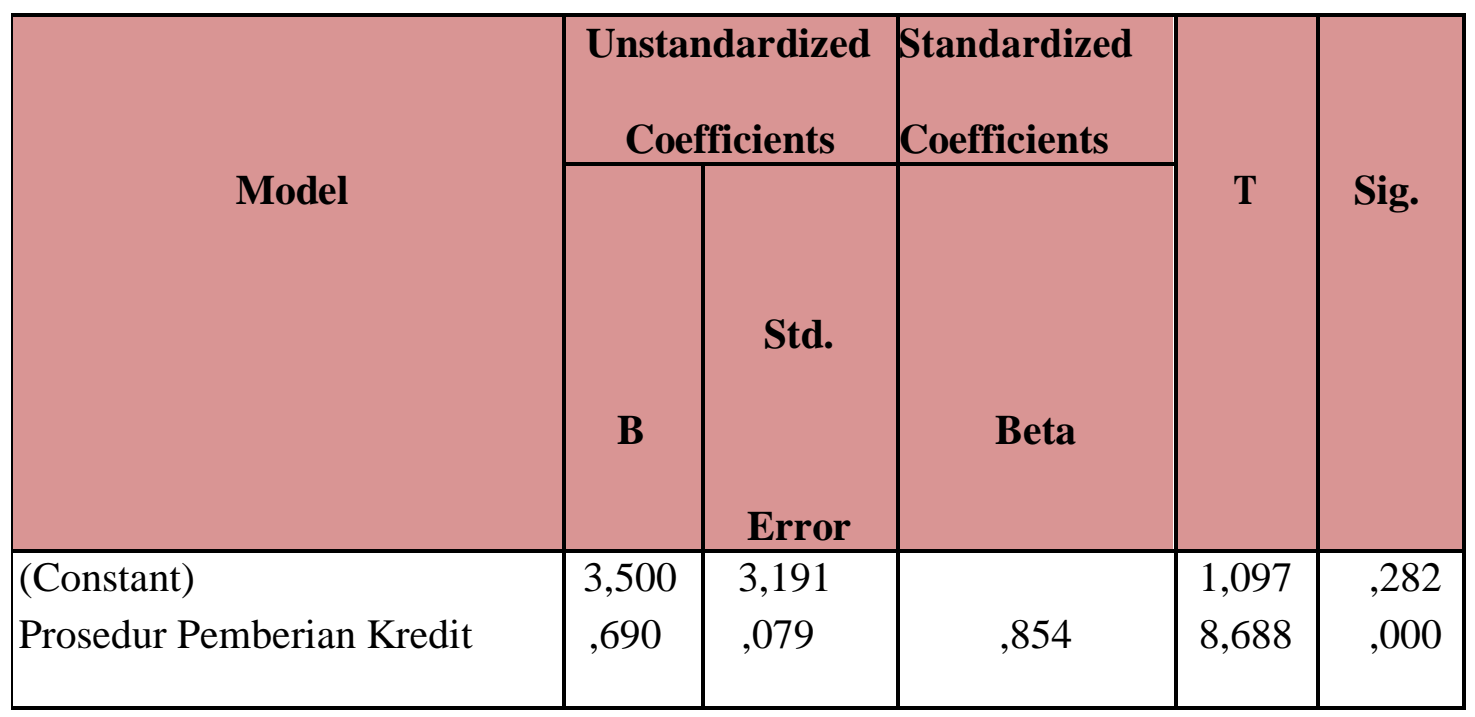

Sumber: Data Olahan SPSS 21, 2018

Untuk kepentingan pengujian ini ditetapkan pasangan hipotesisi statitik sebagai berikut: Terima Ho, jika - ) dengan taraf nyata $\mathrm{a}=0,01$ atau $\mathrm{a}=0.05 \mathrm{dan} \mathrm{dk}=\mathrm{n}-2$ berdasarkan harga $r$ dan $r^{2}$ diatas. Hasil analisis di atas menunjukan bahwa nilai $t_{-h i t u n g}$ untuk variabel Prosedur pemberian kredit diperoleh sebesar 8,688 (dapat dilihat pula pada tabel model regresi) sedangkan nilai t-tabel pada tingkat signfikansi 5\% dan derajat bebas n-k-1 =30-1-1= 28 sebesar 2,048 (Pengujian ini sifatnya dua arah, sebab proposisi hipotesis tidak mengisyaratkan pengaruh variabel bebas terhadap variabel terikat merupakan pengaruh yang positif atau negatif).

Jika kedua nilai t ini dibandingkan maka nilai t-hitung masih lebih besar dibandingkan dengan nilai $\mathrm{t}_{\text {tabel }}(8,688>2,048)$ sehingga $\mathrm{H}_{0}$ ditolak dan $\mathrm{H}_{\alpha}$ diterima. Selain itu apabila kita membandingkan nilai signifikansi atau Probability $\left(\mathrm{P}_{\text {value }}\right)$, maka dapat dilihat bahwa nilai Probability atau $\mathrm{P}_{\text {value }}(0,000)$ dari pengujian ini lebih kecil dari 0.05. Dengan kata lain dapat disimpulkan bahwa terdapat pengaruh yang signifikan dari Prosedur pemberian kredit PT. Nusa Surya Ciptadana (NSC) Finance Cabang Gorontalo terhadap Pengendalian piutang nasabah di PT. Nusa Surya Ciptadana (NSC) Finance Cabang Gorontalo. 


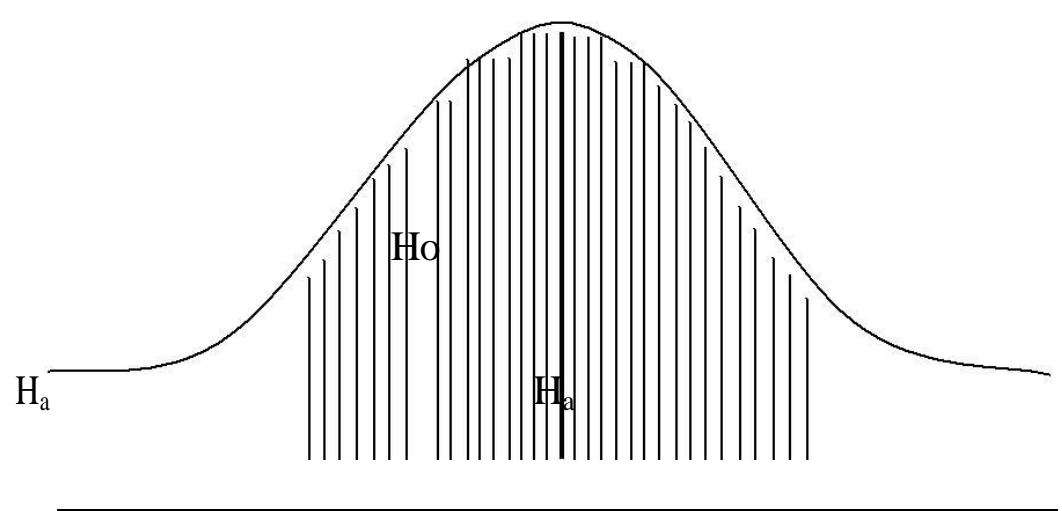

$-2.0480 \quad+2,0488,688$

Gambar 1: Kurva Penolakan dan Penerimaan $\mathrm{H}_{\mathrm{O}}$

Kemudian hasil perhitungan dan tabel 6, maka diperoleh persamaan regresi yaitu:

$$
\begin{gathered}
Y=3,500+0,690 X \\
\text { atau }
\end{gathered}
$$

Pengendalian piutang $=3,500+0,690$ Prosedur pemberian kredit

Berdasarkan model persamaan regresi tersebut, maka dapat diinterpretasikan halhal sebagai berikut:

1. Nilai konstanta sebesar 3,500 menunjukan nilai tetap dari sebuah persamaan dmana jika tidak terdapat pengaruh dari variabel Prosedur pemberian kredit, maka rata-rata nilai dari variabel Pengendalian piutang pada PT. Nusa Surya Ciptadana (NSC) Finance Cabang Gorontalo adalah sebesar 3,500 satuan.

2. Nilai Koefisien Regresi Variabel X (Prosedur pemberian kredit), menunjukan setiap peningkatan variabel Prosedur pemberian kredit sebesar 1 satuan maka Pengendalian piutang sebesar akan mengalami peningkatan (sebab koefisien positif) sebesar 0,690 kali satuan. Sehingga dapat dikatakan bahwa ada pengaruh yang positif. Nilai Koefisien regresi dengan arah postif menunjukan terdapat pengaruh yang baik Prosedur pemberian kredit dalam Pengendalian piutang pada PT. Nusa Surya Ciptadana (NSC) Finance Cabang Gorontalo.

\section{Pembahasan}

Kebangkrutan yang dialami oleh sebagian perusahaan maupun instansi diakibatkan oleh kurang baiknya instansi/perusahaan tersebut mengelola manajemennya, salah satunya dalam pengelolaan manajemen piutang. Dengan bertambahnya jumlah pelanggan, pemasok, 
jumlah dana yang dibutuhkan, merupakan tanda bahwa instansi/perusahaan tersebut semakin berkembang. Tetapi, instansi/perusahaan pun tidak seharusnya menutup mata dengan permasalahan pengendalian piutang yang masih belum bisa diatasi oleh pihak manajemen. Menurut Syakur (2015:104) piutang menunjukkan adanya klaim perusahaan kepada pihak (perusahaan) lain dalam bentuk uang, barang, jasa atau dalam bentuk aktiva non kas lainnya yang harus dilakukan penagihan pada tanggal jatuh temponya. Piutang usaha dapat berupa tagihan yang timbul karena penjualan barang dagangan dan jasa atau penjualan aktiva lainnya yang dilakukan secara kredit dan transaksi-transaksi lainnya.

Sistem pengendalian internal piutang yang diterapkan oleh sebuah instansi tidak menjamin tertagihnya semua piutang pelanggan yang disebabkan oleh beberapa hal, salah satunya semakin meningkatnya kebutuhan hidup dari masyarakat, sehingga seringkali mereka tidak mampu untuk melunasi tagihan kreditnya saat jatuh tempo. Karena perusahaan/instansi yang memberikan jasa dan menjual barang secara kredit tentu tidak lepas dari yang namanya piutang tidak tartagih. Oleh karena itu, perlu adanya upaya dari instansi untuk mengurangi tingkat piutang tidak tertagih dengan memaksimalkan proses penagihan piutang, agar piutang tidak tertagih tidak meningkat setiap tahunnya.

Manajer keuangan harus kontrol ketat jangka waktu penagihan dan skedul umur piutang. Kedua unsur itu harus dihubungkan dengan syarat kredit dan kedua unsur itu untuk mengetahui efektivitas bagian penagihan menjalankan tugasnya. Jika jangka waktu penagihan makin panjang dan rasio umur piutang yang melewati jatuh tempo makin besar, maka harus diadakan peninjauan kembali kebijakan penjualan kredit.Piutang merupakan aspek yang sangat penting, bahkan menurut Ramana (2013) piutang menempati tempat kedua terpentingdalam asset perusahaan setelah persediaan sehingga pada beberapa perusahaan, piutang dijadikan sebuah dasar dalam asset perusahaan.Oleh karena itu penanganannya memerlukan perlakuan yang sangat khusus sehingga kerugian piutang tak tertagih dapat dihindari. Oleh karena itu tidak dapat dipungkiri bahwa pengendalian piutang merupakan suatu perangkat alat yang perlu dilaksanakan dengan sebaik-baiknya, karena piutang yang tidak dapat ditagih merupakan faktor yang akan merugikan perusahaan. Dengan kata lain resiko tidak tertagihnya piutang dari para langganan tetap, adalah tanggung jawab bersama di antara fungsionaris perusahaan Bagi sebagian besar perusahaan/instansi, proses penagihan merupakan pos yang mempunyai peranan penting, karena proses ini merupakan tahapan di mana pos piutang akan dikonversi menjadi uang kas yang selanjutnya akan digunakan pada 
proses operasi perusahaan/instansi pada waktu yang akan datang. Oleh karena itu, pengendalian pada penagihan piutang sangat diperlukan untuk mengurangi kerugian akibat kemungkinan tidak tertagihnya piutang dan juga untuk pembiayaan operasi di masa yang akan datang.

Pengujian secara statistik deskriptif mengenai pengendalian piutang ditemukan bahwa secara keseluruhan persentase skor capaian untuk variabel Pengendalian Piutang adalah sebesar 1.528 satuan atau 84,9\% dengan kategori sangat baik. Hal ini menggambarkan bahwa PT. Nusa Surya Ciptadana (NSC) Finance Cabang Gorontalo aktif dan berupaya untuk melakukan pengendalian piutang yang dilakukan dengan cara penyaringan pelanggan, penentuan resiko kredit, penentuan potongan, pelaksanaan administrasi penagihan piutang dan penentuan ketentuan-ketentuan dalam menghadapi penunggak.

Sementara itu untuk skor indikator dimana skor tertinggi yakni indikator 5 yakni mengenai penentuan ketentuan dalam menghadapi nasabah penunggak dengan skor sebesar 90,67\%. Hal ini menunjukan bahwa pihak karyawan dari PT. Nusa Surya Ciptadana (NSC) Finance Cabang Gorontalo berupaya untuk meminimalisasi adanya kredit bermasalah dengan cara penagihan secara intens dan langkah preventif bagi nasabah lainnya. Sementara itu skor terendah yakni pada indikator 1 yakni mengenai penyaringan pelanggan dengan skor sebesar 80,00\%. Hal ini menunjukan bahwa pihak karyawan dari PT. Nusa Surya Ciptadana (NSC) Finance Cabang Gorontalo masih belum optimal dalam melakukan penyaringan pelanggan atau nasabah, hal tersebut karena keinginan pencapaian target sehingga terdapat banyak hal yang tidak memenuhi namun diloloskan dalam pemberian kredit sehingga hal ini berdampak pada keadaan piutang yang sulit bahkan dalam kategori tak tertagih.

Cepat lambatnya piutang yang dapat dikumpulkan juga dipengaruhi oleh kualitas pelanggan, baik kualitas kemampuan perusahaan pelanggan maupun kualitas karakter pelanggan itu sendiri. Penilaian kualitas pelanggan dimaksudkan untuk mengurangi risiko kemungkinan piutang tidak tertagih dan memperkecil biaya penagihan piutang. Informasi kualitas pelanggan dapat diperoleh dari laporan keuangan, operasi perusahaan, sejarah pengembalian kredit pelanggan, asosiasi pedagang, pesaing, referensi bank dan sebagainya. Salah satu cara untuk menilai kualitas pelanggan tersebut adalah dengan menggunakan penilaian kredit, maka sebelum perusahaan memberikan pijaman atau menambah pinjaman sebelumnya, pihak perusahaan terlebih dahulu mengadakan evaluasi tentang keadaan atau kemampuan ekonomis calon nasabah. 
Besar kecilnya piutang dipengaruhi oleh keadaan ekonomi dan kebijakan penjualan kredit yang dilaksanakan oleh perusahaan yang bersangkutan. Apabila perusahaan menurunkan standar pemberian pinjamannya, maka penjualan akan meningkat yang berarti pula meningkatnya piutang. Meningkatnya piutang perusahaan selain dapat meningkatkan keuntungan, juga perusahaan harus menanggung beban investasi piutang yang besar. Selain dapat meningkatkan keuntungan, juga perusahaan harus menanggung beban investasi piutang yang besar.

Pada prinsipnya pengendalian piutang harus meminimalkan dan mendeteksi serta memperbaiki kesalahan ketika terjadi dalam suatu transaksi piutang. Pelaksanaan pengendalian untuk piutang harus menghasilkan suatu kepastian bahwa semua transaksi piutang telah dibukukan dan dapat dipertanggung jawabkan. Pengendalian terhadap piutang dimulai dari penerimaan order, terus ke proses persetujuan atas order, persetujuan pemberian kredit, pembuatan Purchase order, pembukuan piutang, penagihan piutang, yang akhirnya akan mempengaruhi saldo kas atau bank. Dalam hal ini harus diperhatikan pula retur penjualan secara periodik harus dibuat perincian piutang menurut golongan usianya untuk menentukan tindakan apa yang perlu dilakukan dan menilai apakah bagian kredit dan bagian inkaso telah bekerja dengan efisien. Sehingga dengan demikian pengenalian piutang dapat dilakukan dengan prosedur pemberian kredit yang jelas dan tepat. Kuncoro dan Suhardjono (2002: 245) mengungkapkan bahwa prosedur kredit merupakan upaya lembaga keuangan untuk mengurangi risiko dari pemberian kredit, yang dimulai dengan tahapan penyusunan perencanaan perkreditan, proses pemberian keputusan kredit (prakarsa, analisis dan evaluasi, negosiasi, rekomendasi, dan pemberian keputusan kredit), penyusunan pemberian kredit, dokumentasi dan administrasi kredit, persetujuan pencairan kredit serta pengawasan dan pembinaan kredit.

Prosedur yang dilaksanakan dirancang dengan maksud memudahkan para calon Debitur untuk melaksanakan transaksi kredit. Adapun penyajiannya dalam bentuk langkahlangkah yang harus dilakukan oleh kedua belah pihak, baik oleh pihak Bank atau bukan Bank maupun calon Debitur dengan ketentuan yang berlaku. Hasil analisis deskriptif mengenai prosedur pemberian kredit ditemukan bahwa secara keseluruhan persentase skor capaian untuk variabel Prosedur pemberian kredit adalah sebesar 1.951 satuan atau 86,7\% dengan kategori sangat baik. Hal ini menggambarkan bahwa PT. Nusa Surya Ciptadana (NSC) Finance Cabang Gorontalo dalam memberikan kredit kepada calon nasabah mempersyaratkan 
berbagai kelengkapan berkas serta prosedur yang jelas agar tidak terjadi wanprestasi dari nasabah

Indikator dengan skor tertinggi yakni indikator 4 yakni mengenai pelaksanaan dan administrasi kredit dengan skor sebesar 91,00\%. Hal ini menunjukan bahwa dalam memberikan kredit kepada nasabah, pihak karyawan dari PT. Nusa Surya Ciptadana (NSC) Finance Cabang Gorontalo melakukan pencocokan data bagi kelengkapan berkas yang benarbenar telah memenuhi syarat. Sementara itu skor terendah yakni pada indikator 3 yakni mengenai keputusan kredit dengan skor sebesar 80,89\%. Hal ini menunjukan bahwa pihak karyawan dari PT. Nusa Surya Ciptadana (NSC) Finance Cabang Gorontalo dalam memutuskan untuk memberikan kredit dilakukan seteah hasil analisa memenuhi syarat dan ketentuan dari perusahaan.

Sementara hasil pengujian regresi ditemukan bahwa terdapat pengaruh yang signifikan dari Prosedur pemberian kredit PT. Nusa Surya Ciptadana (NSC) Finance Cabang Gorontalo terhadap Pengendalian piutang nasabah di PT. Nusa Surya Ciptadana (NSC) Finance Cabang Gorontalo. Nilai Koefisien regresi dengan arah postif menunjukan terdapat pengaruh yang baik Prosedur pemberian kredit dalam Pengendalian piutang pada PT. Nusa Surya Ciptadana (NSC) Finance Cabang Gorontalo. Semakin ketat prosedur yang diterapkan oleh perusahaan maka probability terjadinya penunggakan piutang oleh nasabah dapat diminimalisasi.

Sementara itu, nilai koefisien korelasi dari variabel penelitian yakni sebesar 0,854 $(85,4 \%)$. Hal ini berarti bahwa hubungan antara variabel bebas (Prosedur pemberian kredit) dengan variabel terikat (Pengendalian piutang) berada pada kategori hubungan yang kuat. Kemudian hasil analisis koefisien determinasi pada tabel di atas menunjukkan besarnya koefisien determinasi atau angka $R$ Square adalah sebesar 0,729. Nilai ini menunjukan bahwa sebesar 72,9\% variabilitas Pengendalian piutang pada PT. Nusa Surya Ciptadana (NSC) Finance Cabang Gorontalo dapat dijelaskan oleh Prosedur pemberian kredit, sedangkan sisanya sebesar $27,1 \%$ dipengaruhi oleh variabel lain yang tidak diteliti dalam penelitian ini.

Secara keseluruhan maka hasil penelitian ini sejalan dengan teori Kuncoro dan Suhardjono (2002: 245) mengungkapkan bahwa prosedur kredit merupakan upaya lembaga keuangan untuk mengurangi risiko dari pemberian kredityang dimulai dengan tahapan penyusunan perencanaan perkreditan, proses pemberian keputusan kredit (prakarsa, analisis dan evaluasi, negosiasi, rekomendasi, dan pemberian keputusan kredit), penyusunan 
pemberian kredit, dokumentasi dan administrasi kredit, persetujuan pencairan kredit serta pengawasan dan pembinaan kredit. Sebelum memperoleh kredit, debitur terlebih dahulu harus melalui tahapan-tahapan penilaian mulai dari pengajuan proposal kredit dan dokumendokumen yang diperlukan, pemeriksaan keaslian dokumen, analisis kredit sampai dengan kredit dikeluarkan oleh pihak lembaga keuangan. Dan sejalan dengan penelitian yang pernah dilakukan oleh Mointi (2013) yang berjudul Pengaruh Pengendalian Intern Prosedur Pemberian Kredit Terhadap Tingkat Pengembalian Piutang Pada PT. Bank Sulut Cabang Limboto. Berdasarkan analisa kuantitatif terdapat pengaruh yang signifikan antara variabel pengendalian intern prosedur pemberian kredit $(\mathrm{X})$ terhadap tingkat pengembalian piutang (Y) pada PT. Bank Sulut cabang Limboto.

\section{Simpulan}

Berdasarkan hasil analisis dan pembahasan tentang Pengaruh Prosedur Pemberian Kredit Terhadap Pengendalian Piutang, maka dapat ditarik kesimpulan bahwa Prosedur pemberian kredit PT. Nusa Surya Ciptadana (NSC) Finance Cabang Gorontalo berpengaruh positif terhadap Pengendalian piutang nasabah di PT. Nusa Surya Ciptadana (NSC) Finance Cabang Gorontalo. Hal ini ditunjukkan oleh Nilai Koefisien regresi sebesar nilai t-hitung = 8,688 lebih besar dari $t_{-t a b e l}=2,048$ dan nilai signifikansi sebesar 0,000 dari pengujian ini lebih kecil dari 0.05 , dengan arah postif menunjukan terdapat pengaruh yang baik Prosedur pemberian kredit dalam Pengendalian piutang pada PT. Nusa Surya Ciptadana (NSC) Finance Cabang Gorontalo. Sehingga dapat dikatakan semakin ketat prosedur yang diterapkan oleh perusahaan maka probability terjadinya penunggakan piutang oleh nasabah dapat diminimalisasi.

Sementara itu hasil analisis koefisien determinasi pada tabel di atas menunjukkan besarnya koefisien determinasi atau angka $R$ Square adalah sebesar 0,729. Nilai ini menunjukan bahwa sebesar 72,9\% variabilitas Pengendalian piutang pada PT. Nusa Surya Ciptadana (NSC) Finance Cabang Gorontalo dapat dijelaskan oleh Prosedur pemberian kredit, sedangkan sisanya sebesar $27,1 \%$ dipengaruhi oleh variabel lain yang tidak diteliti dalam penelitian ini.

\section{Daftar Pustaka}

Anthony, R.N., Dearden, J., \& Bedford, N.M. (1992). Sistem Pengendalian Manajemen Edisi Keenam Jilid I. Jakarta: Binarupa Aksara 
Pengaruh Prosedur Pemberian Kredit Terhadap Pengendalian Piutang Pada PT. Nusa Surya Cipta Dana (Nsc Finance) Cabang Gorontalo

Baridwan, Z. (2014). Intermediate Accounting Edisi 8. Yogyakarta: BPFE.

DSP, IAPI. 2013. Standar Profesional Akuntan Publik. Jakarta: Salemba Empat.

Duru., Nwakaego, A., Ekwe, M.C., \& Okpe, I.I. (2014). Account Receivable Management And Corporate Performance Of Companies In The Food \& Beverage Industry: Evidence From Nigeria. European Journal Of Accounting Auditing And Finance Research. Vol.2 No.10. 14.

Haryono, J.A. (1987). Dasar-Dasar Akuntansi, Jilid 2 (Edisi Revisi). Yogyakarta: Liberty Yogyakarta.

Hery. (2012). Akuntansi Keuangan Menengah I Edisi 1, Cetakan Pertama. Jakarta: Penerbit PT. Bumi Aksara.

Ikatan Akuntansi Indonesia. (2008). Pernyataan Standar Akuntansi Keuangan, Cetakan Kedua. Jakarta: Salemba Empat.

Irham, F. (2013). Pengantar Manajemen Keuangan Teori dan Soal Jawab. Bandung: Alfabeta.

Kasmir. (2012). Bank dan Lembaga Keuangan Lainnya, Cetakan ke 11. Jakarta: PT Raja Grafindo.

Kuncoro, M., \& Suhardjono. (2002). Manajemen Perbankan. Yogyakarta: BPFE.

Mointi, D.W. (2013). Pengaruh Pengendalian Intern Prosedur Pemberian Kredit Terhadap Tingkat Pengembalian Piutang Pada PT. Bank Sulut Cabang Limboto. Artikel Ilmiah. Hal. 145.

Mulyadi. (2016). Sistem Akuntansi Edisi 4. Jakarta: Salemba Empat.

Munawir. (2004). Sistem Akuntansi. Jakarta: Salemba Empat.

Nisa, H. (2017). Analisis Sistem Pengendalian Intern Persetujuan Kredit Dalam Memperkecil Resiko Piutang Tak Tertagih Pada PT.Nusa Surya Ciptadana Cabang Martapura. Jurnal Ilmiah Ekonomi Bisnis, Vol 3 No 1.

Rachmat, F., \& Maya, A. (2008). Manajemen Perkreditan Bank Umum: Teori, Masalah, Kebijakan, dan Lengkap dengan Analisis Kredit. Bandung: Alfabeta.

Ramana, V. (2013). Impact of Receivable Management on Working Capital and Profitability: A Study On Select Cement Companies In India. Indian Reseach Journal. Vol 2. No 3 . Hal. 9.

Rasyid, B.H. (2016). Metoda Sampling dan Penskalaan. Bandung: Jurusan Statistika Universitas Padjajaran.

Sangadji, E.M., \& Sopiah. (2010). Metodologi Penelitian Pendekatan Praktis dalam Penelitian. Yogyakarta: Andi.

Sari, F.K. (2016). Pengaruh Kualitas Pelayanan Dan Prosedur Kredit Terhadap Keputusan Pengambilan Kredit Dengan Reference Group Sebagai Variabel Moderating Pada Badan Kredit Desa (Bkd) Gombong. Artikel Ilmiah Universitas Negeri Yogyakarta.

Suharsimi, A. (2006). Prosedur Penelitian Suatu Pendekatan Praktek. Jakarta: Rineka Cipta.

Sulistiawan, D., \& Feliana, Y.K. (2006). Akuntansi Keuangan Menengah 1 Edisi 1. Malang: Banyumedia.

Syahril, E. (2015). Pengaruh Intern Piutang Terhadap Minimalisasi Piutang Tak Tertagih pada PT. Al Ijarah Tahun 2014. Jurnal Measurement. Vol. 9 No. 2.

Syakur, S.A. (2015). Intermediate Accounting. Jakarta: AV Publisher.

Warren, C.S., Reeve, J.M., \& Fess, P.E. (2005). Accounting $21^{\text {th }}$ Edition Edisi Satu. Jakarta: Salemba Empat.

--------. 2007. Dasar-dasar Perbankan. Jakarta:Bumi Aksara. 2011. Manajemen: Dasar, Pengertian, dan Masalah. Jakarta:Bumi Aksara. 2011. Manajemen: Dasar, Pengertian, dan Masalah. Jakarta:Bumi Aksara. 